NBER WORKING PAPER SERIES

\title{
ECONOMIC CRISIS, GENERAL LAWS, AND THE MID-NINETEENTH-CENTURY TRANSFORMATION OF AMERICAN POLITICAL ECONOMY
}

\author{
Naomi R. Lamoreaux \\ John Joseph Wallis \\ Working Paper 27400 \\ http://www.nber.org/papers/w27400 \\ NATIONAL BUREAU OF ECONOMIC RESEARCH \\ 1050 Massachusetts Avenue \\ Cambridge, MA 02138 \\ June 2020
}

This paper is forthcoming in the Journal of the Early Republic. We are grateful for the helpful comments of Jeremy Atack, Maggie Blackhawk, Charles Calomiris, Peter Cane, Stephanie Charles, Brian Cheffins, Laura Edwards, Jose-Antonio Espin-Sanchez, Nicole Etcheson, James Fenske, Walter Friedman, Louis Galambos, Gary Gerstle, Glenda Gilmore, Timothy Guinnane, Ron Harris, Eric Hilt, William Janeway, Geoffrey Jones, David Konig, David Lamoreaux, Gregory Mark, John Majewski, Tom Nicholas, William Novak, Sheilagh Ogilvie, Gautham Rao, Eric Rauchway, Paul Rhode, Roberta Romano, Ariel Ron, Laura Phillips Sawyer, Andrew Shankman, Stephen Skowronek, and Francesca Trivellato, as well as two anonymous referees and participants in seminars, lectures, and conferences at Assumption University of Thailand, the German Historical Institute in Washington, DC, Harvard University, the Institute for Advanced Study in Toulouse, New York University, Princeton, Tel Aviv University, the Tobin Project, the Universities of Cambridge, Connecticut, Michigan, and Oxford, Vanderbilt, and Yale. We have also benefitted from the able research assistance of Joseph Doran, Declan Kunkel, Ishwar Mukherjee, and Catherine Peng and the research support of our universities. The views expressed herein are those of the authors and do not necessarily reflect the views of the National Bureau of Economic Research.,

NBER working papers are circulated for discussion and comment purposes. They have not been peer-reviewed or been subject to the review by the NBER Board of Directors that accompanies official NBER publications.

(C) 2020 by Naomi R. Lamoreaux and John Joseph Wallis. All rights reserved. Short sections of text, not to exceed two paragraphs, may be quoted without explicit permission provided that full credit, including $\odot$ notice, is given to the source. 
Economic Crisis, General Laws, and the Mid-Nineteenth-Century Transformation of American Political Economy

Naomi R. Lamoreaux and John Joseph Wallis

NBER Working Paper No. 27400

June 2020

JEL No. K1,K2,N4,N41

\begin{abstract}
Before the middle of the nineteenth century most laws enacted in the United States were special bills that granted favors to specific individuals, groups, or localities. This fundamentally inegalitarian system provided political elites with important tools that they could use to reward supporters, and as a result, they were only willing to modify it under very special circumstances. In the early 1840s, however, a major fiscal crisis forced a number of states to default on their bonded debt, unleashing a political earthquake that swept this system away. Starting with Indiana in 1851, states revised their constitutions to ban the most common types of special legislation and, at the same time, mandate that all laws be general in their application. These provisions dramatically changed the way government and the economy worked and interacted, giving rise to the modern regulatory state, interest-group politics, and a more dynamic form of capitalism.
\end{abstract}

Naomi R. Lamoreaux

Department of Economics

Yale University

27 Hillhouse Ave., Rm. 39

Box 208269

New Haven, CT 06520-8269

and NBER

naomi.lamoreaux@yale.edu

John Joseph Wallis

Department of Economics

University of Maryland

College Park, MD 20742

and NBER

wallis@econ.umd.edu 


\section{Economic Crisis, General Laws, and the Mid-Nineteenth-Century Transformation of American Political Economy}

The General Assembly shall not pass local or special laws, in any of the following numerated cases, that is to say: Regulating the jurisdiction and duties of justices of the peace and of constables; For the punishment of crimes and misdemeanors; Regulating the practice in courts of justice; Providing for changing the venue in civil and criminal cases; Granting divorces; Changing the names of persons; For laying out, opening and working on, highways, and for the election or appointment of supervisors; Vacating roads, town plats, streets, alleys and public squares, Summoning and empaneling grand and petit juries, and providing for their compensation; Regulating county and township business; Regulating the election of county and township officers, and their compensation; For the assessment and collection of taxes for State, county, township or road purposes;

Providing for supporting common schools, and for the preservation of school funds; In relation to fees or salaries; In relation to interest on money; Providing for opening and conducting elections of State, county or township officers, and designating the places of voting; Providing for the sale of real estate belonging to minors, or other persons laboring under legal disabilities, by executors, administrators, guardians or trustees.

—-Indiana Constitution of 1851, Article IV, Section 22

In all the cases enumerated in the preceding section, and in all other cases where a general law can be made applicable, all laws shall be general and of uniform operation throughout the State.

—Indiana Constitution of 1851, Article IV, Section 23

Corporations, other than banking, shall not be created by special act, but may be formed under general laws.

—Indiana Constitution of 1851, Article XI, Section 13

In 1851, in the aftermath of an economic crisis that forced the state into default, Indiana

rewrote its constitution to require that laws enacted by the legislature "be general and of uniform operation throughout the state.” This directive may not seem remarkable from the standpoint of the twenty-first century; we take it for granted that that is what legislatures do. From the perspective of the mid-nineteenth century, however, the provision was groundbreaking. The first 
such mandate ever enacted, Indiana’s innovation spread to almost all the other US states over the next few decades (Figure 1). Although the federal constitution was never similarly amended, the states’ revisions changed the norms for how democratic governments should operate and ultimately reshaped federal practice as well. In this article, we track the history of this fundamental reform and show how it transformed the workings of government and the economy and also the way government and the economy interacted.

Before Indiana's innovation, the main business of legislatures was to enact special or private bills on behalf of specific individuals, organizations, and localities. The year before its new constitution was ratified, for example, Indiana's general assembly passed 550 acts (Table 1). About half benefited particular local governments, granting them permission to spend public funds, borrow money, levy taxes, set salaries, fees, duties, and meeting times for administrators and judges, and take a variety of other actions. Almost all the rest (nearly 40 percent) aided particular individuals or organizations. Some involved personal matters such as divorces, name changes, and the administration of decedents’ estates, but the vast majority conveyed grants of economically valuable privileges such as corporate charters to people specifically named in the bills. $^{1}$

Because some people, groups, and localities were better positioned than others to obtain favors from the legislature, this system of special laws was fundamentally inegalitarian. Indeed, it was precisely because it was inegalitarian that it persisted. The competitive democratic

\footnotetext{
${ }^{1}$ For numbers for other states, see Robert M. Ireland, "The Problem of Local, Private, and Special Legislation in the Nineteenth-Century United States," American Journal of Legal History 46 (July 2004): 271-299. As Farah Peterson has shown, the vacuum created by legislatures' preoccupation with special bills meant that the articulation of general legal rules was left to jurists. See "Interpretation as Statecraft: Chancellor Kent and the Collaborative Era of American Statutory Interpretation,” Maryland Law Review 77 (issue 3, 2018): 712-773.
} 
politics of the early nineteenth century drove governing elites to consolidate their political support by doling out favors to members of their factions and denying them to people who belonged to other groups. Those in power benefited from the ability to dispense charters for banks and other valuable economic organizations. Those out of power complained bitterly about this "corruption," but they behaved in exactly the same way when they were in office, favoring supporters and freezing out opponents. To do otherwise would be to risk losing control of the government and, with that, access to banks and similar advantages.

Despite the discontent the system generated, therefore, it was remarkably persistent. From time to time there were episodes of significant change, and in the next section of the paper we describe two cases, one in Massachusetts and the other in New York, in which fallout from the political award of bank charters led elites to take the unprecedented step of allowing anyone who met a basic set of criteria to form a bank. The resulting increase in the availability of credit delivered significant benefits to the economies of these states, but elites elsewhere resisted giving up the political benefits that the award of bank charters afforded. More widespread change came only with the economic crisis of the early 1840s, when Indiana, seven other states, and one territory defaulted on their bonded debt and several other states teetered on the brink of default. The crisis set in motion a massive political earthquake that overcame elite resistance to change, propelling most of the affected states to revise their constitutions and, ultimately, sweep the system of private and local legislation away.

We document this transformation in the third section of the paper, focusing on Indiana because it was the first state to make the full set of changes. Indiana got into financial trouble because it had borrowed heavily during the late 1830s to fund an extensive system of internal improvements. In order to secure support for a canal across the middle of the state, promoters 
had added funding for numerous smaller projects that benefited specific individuals, organizations, and communities until the bill grew to "mammoth" proportions, to use contemporaries' language. Delegates to the state's constitutional convention understood that if they wanted to prevent such crises from reoccurring they had to reform the way the legislature worked, and they voted by a large margin to ban special and local legislation for a long list of categories, including corporate charters. Hoping to force legislators to shift attention from their own interests and jurisdictions to those of the polity as a whole, they took the additional step of insisting that all laws be general and uniform throughout the state.

Though almost all states eventually followed suit, most initially responded to the crisis with more modest changes. Some added provisions to their constitutions that banned special charters of incorporation but not private bills more generally. Others simply enacted general incorporation laws for business enterprises. Historians have written extensively about these statutes, but have not appreciated the extent to which they were a means of forestalling more farreaching reform. General incorporation laws allowed anyone to form a company and secure basic corporate advantages, but legislatures could and did continue to grant special charters on more favorable terms to political supporters. As we will show, it was only when states wrote provisions into their constitutions that banned such charters that general incorporation laws significantly opened access. And it was only when the prohibition on special charters was accompanied by a mandate that all laws be general that legislators' ability to control the exploitation of valuable economic opportunities for political ends was significantly curtailed. ${ }^{2}$

${ }^{2}$ For the most complete count of general incorporation laws for manufacturing companies, see Eric Hilt, "Corporation Law and the Shift toward Open Access in the Antebellum United States,” in Organizations, Civil Society, and the Roots of Development, ed. Naomi R. Lamoreaux and John Joseph Wallis (Chicago: University of Chicago Press, 2017), 147-177. See also James Willard Hurst, The Legitimacy of the Business Corporation in the Law of the United 
The final section of this article sketches the transformation in American political economy that resulted from these more fundamental reforms. Historians of American state formation have been preoccupied in recent years with the question of whether the United States had a strong or weak state, and in particular whether the national government played an important role in the economy before the twentieth century. William Novak has made a useful intervention in this debate by showing that proponents of the weak-state view have been misled by Weberian notions of the state as a distinct, centralized, rationalized, bureaucratic entity. Such a perspective might work well for Europe, Novak argues, but it does a poor job of describing governance in federally structured societies like the US, where overlapping jurisdictions and the divided nature of authority permitted an ongoing and extraordinarily deep "penetration of the state through civil society.”3

That there was such a penetration of the state into civil society throughout US history seems to us incontrovertible, but, we would argue, its terms were fundamentally restructured by the state constitutional revisions of the mid-nineteenth century. So long as corporations were products of specific political deals, governments had little ability to regulate their activities,

States, 1780-1970 (Charlottesville: University Press of Virginia, 1970); and Ronald E. Seavoy, The Origins of the American Business Corporation, 1784-1855: Broadening the Concept of Public Service during Industrialization (Westport, CT: Greenwood, 1982). For a count of special charters enacted after the passage of general incorporation laws, see Susan Pace Hamill, "From Special Privilege to General Utility: A Continuation of Willard Hurst's Study of Corporations," American University Law Review 49 (Oct. 1999): 81-180.

${ }^{3}$ William J. Novak, "The Myth of the 'Weak' American State," American Historical Review 113 (June 2008): 752-772 at 767. Major works on American state formation include Stephen Skowronek, Building a New American State: The Expansion of National Administrative Capacities, 1877-1920 (New York: Cambridge University Press, 1982); Brian Balogh, A Government out of Sight: The Mystery of National Authority in Nineteenth Century America (New York: Cambridge University Press, 2009); and Gary Gerstle, Liberty and Coercion: The Paradox of American Government from the Founding to the Present (Princeton, NJ: Princeton University Press, 2015). 
regardless of the restrictions that might be embedded in their charters. Only when they were products of general laws and not the privileged creatures of legislative favoritism could modern regulatory institutions emerge. And they did. The constitutional revisions drafted in the wake the defaults gave form to the resentments of white male voters disadvantaged by the system of legislative favoritism, and as a result, the general incorporation statutes that followed included numerous restrictions that aimed to level the playing field. As we will show, these regulationladen laws succeeded in extending corporate advantages to an enormous number of small- and medium-sized enterprises. Although they did not also prevent railroads and other large-scale businesses from amassing considerable market power, most states responded to this new threat by beefing up their regulatory capabilities, creating formal commissions to limit the rates charged by railroads and other public-service corporations, and enacting antitrust laws with significant bite. ${ }^{4}$

The state constitutional revisions also transformed the ways in which the wealthy and powerful lobbied the government—or, to put the matter more bluntly, their methods of corruption. Before the reforms, business people had mainly agitated for private bills that specifically benefitted their own enterprises; afterwards, they discovered they had a common interest in influencing the content of general laws, and they began to organize—and spend

${ }^{4}$ Tony A. Freyer, Producers versus Capitalists: Constitutional Conflict in Antebellum America (Charlottesville: University Press of Virginia, 1994); Naomi R. Lamoreaux, "Corporate Governance and the Expansion of the Democratic Franchise: Beyond Cross-Country Regressions," Scandinavian Economic History Review 64 (issue 2, 2016): 103-121; William R. Childs, The Texas Railroad Commission: Understanding Regulation in America to the MidTwentieth Century (College Station: Texas A\&M University Press, 2005); James May, "Antitrust Practice and Procedure in the Formative Era: The Constitutional and Conceptual Reach of State Antitrust Law, 1880-1918," University of Pennsylvania Law Review 135 (Mar. 1987): 495-593; William J. Novak, "The Public Utility Idea and the Origins of Modern Business Regulation,” in Corporations and American Democracy, ed. Naomi R. Lamoreaux and Novak (Cambridge, MA: Harvard University Press, 2017): 139-176. 
money — for their collective advantage. At the same time, however, the shift to general laws facilitated the formation of new kinds of voluntary associations that arose to counter the economic power of big business, giving rise to the myriad of organizations that Elisabeth Clemens has called the "people’s lobby." Corruption by no means went away and in some ways may even have intensified, as the organs of the people's lobby repeatedly claimed. But to focus on the extent of corruption, as the literature on the gilded age mainly does, is to obscure the fundamental change in political economy that occurred during this period. Our goal in this paper is to redress that imbalance. ${ }^{5}$

\section{Banking and the First Steps toward General Laws in Massachusetts and New York}

The most conspicuous examples of how governing elites put economic privileges to political use after the Revolution come from the banking sector. Bank charters played an important role in coalition building during this period for the simple reason that the privileges they conferred were extraordinarily valuable. Because the new nation was born without any formal financial institutions to extend credit, the small number of banks that the state and federal governments began to create in the 1780 s were highly prized. Not only could they secure lendable funds at low cost by issuing currency, but the favored few who controlled them had preferred access to credit and also the power to determine who else could obtain loans. ${ }^{6}$

${ }^{5}$ Elisabeth S. Clemens, The People's Lobby: Organizational Innovation and the Rise of Interest Group Politics in the United States, 1890-1925 (Chicago: University of Chicago Press, 1997); John Joseph Wallis, “The Concept of Systematic Corruption in American History,” in Corruption and Reform: Lessons from America's Economic History, ed. Edward L. Glaeser and Claudia Goldin (Chicago: University of Chicago Press, 2006), 23-62.

${ }^{6}$ Naomi R. Lamoreaux, Insider Lending: Banks, Personal Connections, and Economic Development in Industrial New England (New York: Cambridge University Press, 1994), Ch. 1. 
Perhaps better than anyone, Alexander Hamilton understood the political value of banks in the credit-scarce environment of the Early Republic. His efforts in Washington's first administration to use the Bank of the United States to build an elite coalition in support of the national government and its Federalist leadership are well known. Even earlier he and his political allies had organized the Bank of New York, and they had succeeded in blocking all attempts by competing groups to found banks in the state until 1799, when DemocraticRepublican Aaron Burr exploited a loophole in the charter of a water company to start the Manhattan Bank. Burr's allies credited the maneuver with the destruction of the Federalists' "empire" in New York, boasting that the new bank "emancipated hundreds who were held in bondage by the old institutions." However exaggerated that claim, there is no question that the Democratic-Republicans used the Manhattan Bank for political ends, offering supporters loans to reward their loyalty. Gaining control of the New York legislature in 1803, they founded a second bank for the benefit of their supporters and, at the same time, refused to charter one for the Federalists. When the latter went into operation anyway as a joint-stock partnership, the legislature responded by passing a restraining act that prohibited any association from operating as a bank without a charter. Although a Federalist resurgence subsequently enabled the bank to secure the necessary charter, the restraining act remained in effect, giving whichever party was in office still greater power to control access to banking. ${ }^{7}$

${ }^{7}$ Bray Hammond, Banks and Politics in America: From the Revolution to the Civil War (Princeton, NJ: Princeton University Press, 1957), Ch. 5; David Jack Cowen, The Origins and Economic Impact of the First Bank of the United States, 1791-1797 (New York: Garland Publishing, 2000), Ch. 1; Brian Phillips Murphy, “'A Very Convenient Instrument”: The Manhattan Company, Aaron Burr, and the Election of 1800," William and Mary Quarterly 65 (April 2008): 233-266 at 233; Murphy, Building the Empire State: Political Economy in the Early Republic (Philadelphia: University of Pennsylvania Press, 2015), Chs. 1 and 3; Eric Hilt, "Early American Corporations and the State," in Corporations and American Democracy, ed. Lamoreaux and Novak, 37-73; Howard Bodenhorn, "Opening Access: Banks and Politics in 
A similar dynamic shaped the early history of banking in Massachusetts. The state had chartered the Massachusetts Bank in Boston in 1784 as a monopoly that would serve the interests of the government as well as the dominant Federalist elite. The bank was too small to meet the credit needs of all the Federalists who needed accommodation, however, so the legislature chartered a second bank in Boston and a small number of additional banks in other locations. Members of rival political groups clamored for institutions of their own, especially after the legislature passed a restraining act in 1799 that prohibited banks from operating without charters, but they were repeatedly rebuffed. ${ }^{8}$

Over the next decade, support for Federalist candidates gradually declined, and in 1811 the Democratic-Republicans won control of both houses of the Massachusetts legislature and also the governorship. Moving immediately to capitalize on their victory, they founded two new banks. One, in Salem, rewarded supporters who had long sought to form a bank there. The other, in Boston, was ostensibly a public institution. Called the State Bank, it was capitalized at $\$ 3,000,000$, three times the size of the largest bank previously chartered in the commonwealth. The government would supply at least a third of its capital, and the bank would return a portion of its profits to taxpayers in the form of dividends on the state's shares. It would also pay an annual tax amounting to 0.5 percent of its paid-in capital. Eleven of the bank's twelve initial directors were Democratic-Republicans, however, suggesting that the bank was intended operate in the interests of that party as well. ${ }^{9}$

New York from the Revolution to the Civil War,” NBER Working Paper 23560 (June 2017). ${ }^{8}$ Lamoreaux, Insider Lending, 11-13; Qian Lu, From Partisan Banking to Open Access: The Emergence of Free Banking in Early Nineteenth Century Massachusetts (Basingstoke, UK: Palgrave Macmillan, 2017); Lu and John Joseph Wallis, "Banks, Politics, and Political Parties: From Partisan Banking to Open Access in Early Massachusetts," in Organizations, Civil Society, and the Roots of Development, ed. Lamoreaux and Wallis, 109-145.

${ }^{9}$ Lu and Wallis, "Banks, Politics, and Political Parties"; and Lu, Partisan Banking, Ch. 2. 
Not content to found their own banks, the victors sought to inflict real harm on their opponents. The charters of all but one of the state's existing banks were set to expire in 1812, and Democratic-Republican legislators vowed to block their renewal. They were unable to make good on this threat when the Federalists retook the lower house and governorship in 1812. Instead, the two parties compromised. The act creating the State Bank had mandated that its terms, including the tax on capital, would apply to all future banks approved by the legislature, and this condition held. The Federalists got their banks rechartered, but now all were subject to the same "rules, restrictions, limitations, taxes and provisions, and entitled to the same rights, privileges and immunities” as the State Bank. ${ }^{10}$

Given the increasing competitiveness of elections in the state, this close brush with nonrenewal seems to have prompted both parties to rethink their coalition-building strategies and agree at least tacitly to take banking off the political table. Although only a few banks were chartered during the turbulent war and depression years that followed, when economic conditions improved during the early 1820s and the demand for bank charters once again increased, the legislature responded by granting most of them. As a result, by the height of the 1830s boom there were nearly 130 banks in the state, and Massachusetts' citizens were better served by banking institutions—-that is, there was more bank capital and more currency per

The Democratic-Republicans took a variety of other steps to entrench themselves in power, including famously redrawing the state's senatorial districts (giving rise to the term "gerrymandering" after the governor who signed the bill into law). See Elmer Cummings Griffith, The Rise and Development of the Gerrymander (Chicago: Scott, Foresman and Co., 1907), Ch. 2.

${ }^{10}$ See, for example, Massachusetts General Court, "An act to incorporate the President, Directors and Company of the Boston Bank," approved June 23, 1812. The tax provision in the State Bank's charter was made general at the same time in "An Act imposing a Tax on the Banks within this Commonwealth," approved June 23, 1812. Unless otherwise noted, all state statutes referenced in this paper can be found in the Session Laws collected on www.heinonline.org. See also Lu and Wallis, "Banks, Politics, and Political Parties”; and Lu, Partisan Banking, 31-32. 
capita in the state — than anywhere else in the US except Rhode Island, which had adopted a similarly liberal chartering policy. All the new banks paid the 0.5 percent tax on their capital, and the state’s soaring tax revenues undoubtedly helped reinforce the new arrangement. In 1830, the first year for which data is available, the tax on bank capital accounted for fully 61 percent of the state's revenue. Indeed, thanks to the bank tax, Massachusetts did not have to impose any property or poll taxes on its citizens in half of the years between 1826 and $1855 .^{11}$

What mattered most in the long run, however, was the commitment that all bank charters would henceforth be the same. This agreement was formalized in 1829 when the legislature passed a new statute specifying the rules under which all banks would operate. The crucial clause stipulated that if "any new or greater privileges shall be granted to any other Bank ..., each and every Bank in operation at the time shall be entitled to the same.” Although this clause technically did not mandate general incorporation, it had a similar effect. From then on, whenever the Massachusetts legislature considered chartering a new bank or changing the charter of an existing one, every bank in the commonwealth was potentially affected. No longer would it be possible for any individual or group to secure a special deal. ${ }^{12}$

In New York, as in Massachusetts, power shifted from the Federalists to the DemocraticRepublicans on the eve of the War of 1812, and the latter took advantage of the opportunity to charter additional banks for their supporters. Unlike in Massachusetts, however, the Federalists

${ }^{11}$ Lamoreaux, Insider Lending, Ch. 3; Lu and Wallis, "Banks, Politics, and Political Parties"; Richard Sylla, John B. Legler, and John Joseph Wallis, "Banks and State Public Finance in the New Republic: The United States, 1790-1860,” Journal of Economic History 47 (June 1987): 391-403; Wallis, Sylla, and Legler, "The Interaction of Taxation and Regulation in Nineteenth-Century U.S. Banking,” in The Regulated Economy: A Historical Approach to Political Economy, ed. Claudia Goldin and Gary D. Libecap (Chicago: University of Chicago Press, 1994), 121-144. 28, 1829.

12 Massachusetts General Court, “An Act to regulate Banks and Banking,” approved Feb. 
never regained control of state government. Instead, during the ensuing "Era of Good Feeling," Martin Van Buren's Democratic-Republican faction used its power over bank charters and other sources of patronage to build a formidable political machine, the Albany Regency. During the economic boom of the 1830s, the New York legislature received an average of about 70 petitions for bank charters each year, but under the machine’s tight control it granted only about ten percent of them, all for the benefit of its political supporters. ${ }^{13}$

The high rejection rate increased the value of charters, but it also fueled discontent. As a result, when the Panic of 1837 brought down the banking system, the Regency fell too. The opposition—now called the Whig Party—took advantage of the collapse to pass an innovative "free banking" law in 1838 that made bank charters freely (that is, routinely) available to any applicants who satisfied the provisions of the act. In that way, the Whigs met the pent-up demand for charters and at the same time insured that the Regency would never again be able to control access to banks for political ends. To counter worries that opening access to banking would undermine the system's soundness, the legislature required banks to back their currency issues with investments in specific categories of government (mainly New York) bonds. The result was a dramatic expansion in the number of banks and an improved market for the state's debt. $^{14}$

${ }^{13}$ Howard Bodenhorn ("Opening Acess”) has "followed the money” to show precisely how the Regency used the award to charters to enrich its minions. See also Bodenhorn, "Bank Chartering and Political Corruption in Antebellum New York: Free Banking as Reform," in Corruption and Reform, ed. Glaeser and Goldin, 231-257; Hilt, "Early American Corporations"; and Seavoy, American Business Corporation, Ch. 4.

${ }^{14}$ New York Legislature, “AN ACT to authorize the business of banking,” passed April 18, 1838; Bodenhorn, "Bank Chartering," 240-244; Seavoy, American Business Corporation, Ch. 6. 
New York's demonstration of the benefits that could be reaped by opening access to banking was not sufficient to induce other states to adopt the innovation. In most places elites were able to weather the turbulence of the 1837 crisis, and they were not willing to relinquish such a valuable instrument of dominance voluntarily. Not until the political earthquake that followed the state defaults of the early 1840 s was change forced upon them. Yet there was a significant economic cost to the delay. The magnitude of the loss can be seen by comparing the growth of bank capital per capita in New York with that in Pennsylvania, another MiddleAtlantic state with a major port, important industrial sector, and large prosperous farming region. Although in 1837 the amount of bank capital per capita in the two states was roughly the same (\$16.43 and \$14.86 respectively), New York opened a significant lead with the enactment of its free banking law. By the time Pennsylvania finally adopted free banking in 1860, the amount of bank capital per capita in the state had fallen to $\$ 8.80$, whereas in New York it had grown to \$28.72. Massachusetts, which had effectively opened access to banking in the 1820 s, was even further ahead, with $\$ 54.00$ of bank capital per capita in $1860 .{ }^{15}$

The enactment of free banking legislation marked the beginning of prudential regulation. States could not exercise any significant degree of oversight of banks when the people who ran them were privileged recipients of legislative favors. It was only when entry into the financial sector was reasonably free of political manipulation—when the rules to which banks were subject were uniform and not dependent on the provisions embedded in their individual charters - that policy makers could begin to grapple with the problem of financial instability. Thus Massachusetts responded to the Panic of 1837 by creating a Board of Bank Commissioners with the authority, if needed, to examine all the banks in the state. New York's free banking act

${ }^{15}$ Bodenhorn, "Bank Chartering," 239, Table 7.1. 
required banks to file regular twice-yearly reports with the state comptroller, who also had authority to sell off the bonds they had deposited to back their currencies in the event of a default. Ohio’s variant of the New York law, enacted in 1851, mandated yearly examinations of all the banks in the state. Under the National Banking Acts, which were modeled on the Ohio statute, the US Comptroller of Currency deployed professional examiners to conduct thorough inspections of all the banks in the system at least once each year, with the most important institutions subject to more frequent scrutiny. ${ }^{16}$

\section{The Political Earthquake of the 1840s}

During the early 1840s eight states (Arkansas, Illinois, Indiana, Louisiana, Maryland, Michigan, Mississippi, and Pennsylvania) and the territory of Florida defaulted on their bonded debt, and several other states, including Alabama, New York, Massachusetts, and Ohio, narrowly avoided a similar fate. The crisis resulted from the enormous debt obligations the states had incurred over the previous decade-in the North mainly to build transportation systems, and in the South mainly to finance mortgage banks in support of plantation agriculture. Most of Southern states that defaulted subsequently repudiated their debts. The Northern states, by contrast, mostly settled with creditors and resumed interest payments on their bonds, gaining voters' support for the higher taxes that resumption necessitated by making fundamental changes in the way their governments worked. Indiana took the reform process further than the rest,

${ }^{16}$ Massachusetts General Court, “An Act providing for the appointment of Bank Commissioners,” approved Feb. 23, 1838; New York Legislature, “AN ACT to authorize the business of banking," passed April 18, 1838; Ohio General Assembly, “AN ACT to authorize Free Banking,” approved Mar. 21, 1851; Hilt, "Early American Corporations.” Of course, bank regulation could itself be a source of financial instability. For example, the National Banking Acts' inflexible currency and pyramiding of reserves in New York City exacerbated many of the banking crises of the late nineteenth and early twentieth century. 
revising its constitution to ban most types of special and local legislation and mandating that laws be general whenever possible. Most of the other Northern states that defaulted initially just banned special charters of incorporation, but later they revised their constitutions on Indiana's model. ${ }^{17}$

On the surface the connection between the Northern states' fiscal problems and the reaction against special and local legislation might seem difficult to fathom. After all, the transportation improvements at the root of the defaults were large (mostly) public works projects that promised benefits to everyone, from small landowning farmers to wealthy big-city merchants. It does not take much digging, however, to see that the projects' most problematic features were outcomes of legislative favoritism. At the most obvious level, the projects were the brainchildren of political and economic elites who stood to benefit from their construction. In New York, for example, the Erie Canal was pushed by DeWitt Clinton as a way of reviving his political career and solidifying support for his Democratic-Republican faction, as well as by land companies seeking profitably to unload their upstate real-estate holdings. But the more salient connection with the system of private and local laws was the way the projects were put together - the political deals that accounted both for their massiveness and for the precarious way in which they were financed. ${ }^{18}$

${ }^{17}$ It is beyond the scope of this paper to explain the Southern states' different response, but very briefly it resulted from popular resentment of plantation banks and from a reluctance to open up the possibility of fundamental reforms that might jeopardize the institution of slavery. John Joseph Wallis, "Constitutions, Corporations, and Corruption: American States and Constitutional Change, 1842-1852,” Journal of Economic History 65 (Mar. 2005): 211-256; Howard Bodenhorn, State Banking in Early America: A New Economic History (New York: Oxford University Press, 2002), Ch. 9; Larry Schweikart, Banking in the American South from the Age of Jackson to Reconstruction (Baton Rouge: Louisiana State University Press, 1987); Sharon Murphy, "Free Banking in Louisiana during the 1850s," unpublished conference paper (2018).

${ }^{18}$ Nathan Miller, The Enterprise of a Free People: Aspects of Economic Development in 
The basic problem that elites faced in securing support for transportation projects was the diverse interests of voters in different parts of their states. How could a legislature that operated on the principle of majority rule fund a project that benefited a minority of districts but potentially imposed higher taxes on all? One way of securing the necessary assent was logrolling—adding goodies for enough districts to secure a majority. A second was to convince residents that they would not have to pay for improvements that did not benefit them. If a canal raised land values in its vicinity, for example, by assessing an ad valorem property tax the state could insure that the beneficiaries shouldered the cost. States could also turn to "taxless" finance. The most common method, especially early on, was to confer a privilege on a group of private individuals—a monopoly on a bridge location, for example—-that the group could exploit only if it built the improvement. Another method, which became increasingly popular after the success of the Erie, was to borrow more money than the project required, pay the interest on the debt in the early years out of borrowed funds, and later, when the project began generating income, use the revenue stream to retire the debt. ${ }^{19}$

Indiana was a large state geographically, and much of its rich agricultural land was far from existing waterways. There had long been interest in a canal that would bisect the northern half of the state and make commercial production feasible there, but legislators faced the usual problem that residents in other parts of the state, particularly farmers along the Ohio River who already had ready access to markets, were unwilling to pay for transportation projects from which they did not expect to benefit. Political leaders overcame these objections by shifting

New York State during the Canal Period, 1792-1838 (Ithaca, NY: Cornell University Press, 1962), Ch. 3-4.

${ }^{19}$ Wallis, “Constitutions, Corporations, and Corruption”; Carter Goodrich, Government Promotion of American Canals and Railroads, 1800-1890 (New York: Columbia University, 1960). 
from a per-acre to an ad valorem tax and by extending the tax to all kinds of property—not just land. The new tax system insured that those who would benefit most from the transportation improvements in terms of higher land values or better trading opportunities would bear the cost. Moreover, because the tax base would grow, farmers with valuable land along the Ohio River could credibly be promised that they would not face a tax increase. These measures were not in themselves enough to secure approval of the canal project, however, because other areas that needed transportation improvements were unwilling to support the bill unless their projects were included. Some of these needs could be met by chartering corporations, but most required grants. Promoters, therefore, had to increase the project's scale (and the amount the state would have to borrow) until the expected improvements benefited most of the districts in the state. The resulting plan, popularly known as the Mammoth Internal Improvement Bill, funded a state-wide system of canals, railroads, and turnpikes with a total projected cost of more than $\$ 10$ million (see Figure 2). The bill was shepherded through the legislature by the Whigs, who controlled both houses as well as the governorship, but it attracted substantial Democratic support and passed in January 1836 by overwhelming majorities in both houses of the legislature. Its success was the result of a deliberate but transparent manipulation of local economic interests to build a broad coalition in support of the project. ${ }^{20}$

The bill created a Board of Internal Improvement and authorized it to borrow up to $\$ 10$ million in 5 per cent bonds, secured by the good faith and credit of the state. At that time,

${ }^{20}$ Indiana General Assembly, "AN ACT to provide for a general system of Internal Improvements,” approved Jan. 27, 1836; John Joseph Wallis, “The Property Tax as a Coordinating Device: Financing Indiana’s Mammoth Internal Improvement System, 18351842," Explorations in Economic History 40 (Jul. 2003): 223-250; Donald F. Carmony, Indiana, 1816-1850: The Pioneer Era (Indianapolis, IN: Indiana Historical Bureau \& Historical Society, 1998); Logan Esarey, A History of Indiana, Vol. 1, From Its Exploration to 1850 (Indianapolis, IN: W. K. Stewart, 1915). 
Indiana's annual revenues amounted to about $\$ 60,000$ - a full order of magnitude smaller than the $\$ 500,000$ per year that would be needed yearly to service the debt. The plan was not quite as reckless as these numbers make it seem, however. Indiana officials had good reason to expect that revenues would more than double in the early 1840s, when the public lands already sold by the federal government would come on the tax rolls. Moreover, under the new ad valorem tax system, revenues would increase as land values appreciated with improved transportation. Of course, these expectations depended on the economy continuing to prosper, on the transportation projects being completed, on settlers migrating to localities with improved access to markets, on land values rising. When a major financial crisis in 1839 brought construction to an abrupt halt, the whole enterprise fell apart. ${ }^{21}$

The proximate cause of the state's troubles was the default of the Morris Canal and Banking Company, which Indiana (along with several other states) had hired as an intermediary to sell its bonds. Indiana officials had given the Morris Company millions of dollars in bonds on credit to sell on its behalf in exchange for a promise to pay the state $\$ 500,000$ every six months until the debt was paid off. Because the state had relied on these transfers to finance construction, when the bank informed the state in the summer of 1839 that it could no longer make the promised semiannual payments, work on the transportation system had to be halted. With construction at a standstill, property values, which had risen speculatively on the expectation of improved access to markets, plummeted, as did tax revenues-from about $\$ 300,000$ in 1840 to about $\$ 170,000$ in 1841 . Worse still, the state turned out to be liable for

${ }^{21}$ Wallis, "Property Tax as a Coordinating Device.” 
interest on the full amount of the bonds, even though it had only been paid for a portion of them. Unable to muster the necessary resources, the state defaulted in January of $1841 .^{22}$

The collapse of the internal improvement scheme threw Indiana's politics into turmoil. The Whigs had dominated state government during the 1830s, and Democrats successfully blamed them for the state's problems, accusing them of corruption and pointing especially to the arrangement with the Morris Bank. The catastrophe could not be explained away so easily, however, since most Democratic legislators had also voted for the bill. As one politician later acknowledged, news of the bill's passage had been greeted with celebrations and fireworks across the state. In Indianapolis "there was a general rejoicing; every pane of glass in the city was illuminated; and the population turned out on the streets as upon a great holiday.” Political leaders had systematically manipulated the interests of legislators and their constituents to build a broad coalition in support of the project, but every aspect of the deal had been transparent, above board, and legal. The logrolling that produced the Mammoth bill had thrived in an environment where special bills predominated. Railing about corruption would not prevent such debacles in the future; the problem had to be eradicated at its root. ${ }^{23}$

By the time a constitutional convention was first seriously proposed in 1846, banning special bills was already at the top of the list of reforms being promoted at public meetings around the state. Democratic Governor James Whitcomb focused on the issue in his December

22 John Joseph Wallis, “What Caused the Crisis of 1839?” NBER Historical Working Paper 133 (Apr. 2001); Esarey, History of Indiana, Vol. 1, Ch. 16.

${ }^{23}$ Indiana, Report of the Debates and Proceedings of the Convention for the Revision of the Constitution (Indianapolis: A. H. Brown), Vol. 1, 675. For the Democrats' charges, see "Madison Railroad," Indiana Democrat, Jan. 9, 1841; letter from “A Tax-Payer,” Indiana Democrat, Jan. 13, 1841; “Milton Stapp, Esq..” Indiana Democrat, Jan. 22, 1841; “Address of the Democratic Members of the Legislature," Indiana Democrat, Feb. 18, 1841. See also Esarey, History of Indiana, Vol. 1, Ch. 16; and Paul Fatout, Indiana Canals (West Lafayetts, IN: Purdue University Studies, 1972). 
1845 message to the legislature, and he continued to push for it in subsequent remarks, declaring in an 1848 address that banning special legislation was such a pressing issue that "[i]f calling a convention to amend the constitution were productive of no other result than furnishing an effectual remedy for this growing evil, it would be abundantly justified.” Governor Paris C. Dunning echoes these remarks when he announced in 1849 that voters had approved the call for a constitutional convention, underscoring the "well founded opposition [that] exists in the public mind" to the "growing evil" of special legislation By 1850 the groundswell was so strong that even the state's Whigs agreed that special legislation was "a fruitful source of evil" and that "some general provision ought to be adopted [at the convention] having reference to incorporations, county business, and other subjects of legislation, heretofore unnecessarily multiplied."24

Given the state's fiscal troubles, one might assume that a restriction on state borrowing would have been the central goal of the delegates arriving at the convention. Certainly, they favored such a measure and voted overwhelmingly to prohibit future borrowing by the state except under emergency circumstances. But limiting the state’s ability to borrow ranked relatively low on the lists of reforms they proposed when they gathered in the capital. For example, the first list submitted for the delegates' consideration had it only fifth, after proposals to mandate "That corporations shall be created under a general law," "That special legislation shall be prohibited," and "That the Legislature shall be prohibited from granting divorces."

${ }^{24}$ Charles Kettleborough, Constitution Making in Indiana: A Source Book of Constitutional Documents with Historical Introduction and Critical Notes (Indianapolis: Indiana Historical Commission, 1916), Vol. 1, lxiv-lxv, 167-169, 185-189, 194-196; Indiana, Documents of the General Assembly (Indianapolis: J. P. Chapman, 1846), Pt 1, 87-96; "Governor’s Message," Wabash Courier, Dec. 12, 1846; and “Whig Resolutions,” Wabash Courier, Feb. 16, 1850. 
Other proposals had a similar ordering of priorities, and among the standing committees set up to draft sections of the new constitution were groups "On Special and Local Legislation, and Uniformity of Laws,” "On Currency and Banking,” “On Corporations other than Banking,” as well as “On State Debt and Public Works” and “On Finance and Taxation.”25

The proposal to end the system of special and local legislation had widespread support at the convention, prompting numerous speeches that linked the "evil” to the state’s fiscal debacle. Almost no one spoke against the ban, and provision passed overwhelmingly on its third reading by a vote of 116 to 13 . The only real debate concerned whether the constitution should simply declare that "the General Assembly shall not pass local or special laws" or whether it should enumerate the kinds of special laws that would be prohibited. In the end the constitution did both, listing nearly a score of specific types of special legislation that would be banned but also mandating that "in all other cases where a general law can be made applicable, all laws shall be general and of uniform operation throughout the state.” Once the constitution was ratified, moreover, there was no going back. The Democrats dominated the legislature during the next couple of sessions, and they got to work revising existing statutes and enacting new general laws where needed. When the new Republican Party took control of the lower house in 1855, its leaders tried to amend the constitution in several ways, including restoring some ability to enact local legislation. But their efforts failed, even in the House. ${ }^{26}$

The sequence of events in other Northern states that defaulted was similar. Regardless of the party in power when the crisis struck, all responded to the resulting political upheaval by

${ }^{25}$ Indiana, Report of the Debates, Vol. 1, 40, 43, 52, 58.

${ }^{26}$ For examples of speeches, see Indiana, Report of the Debates, Vol. 1, 369, 683; Vol. 2, 1032, 1041, 1768-1769. See also Carmony, Indiana, 1816-1850, 416-419; Kettleborough, Constitution Making in Indiana, Vol. 2, 8-12. 
revising or amending their constitutions to restrict legislative borrowing without voter approval. More significantly, all (except Pennsylvania, which had just adopted a new constitution in 1837) wrote new constitutions that curbed the power of legislatures in more fundamental ways. Although none went as far as Indiana and mandated that laws be general and uniform throughout the state, all prohibited their legislatures from chartering corporations except under general laws. Three Northern states with high debt levels that did not default (New York, Ohio, and Wisconsin) also revised their constitutions to ban special corporate charters (see Table 2).

Most other states responded to demands for reform by enacting general incorporation laws. As late as 1840 there were only four states with such laws in force for manufacturing companies; by 1860 all but five out of thirty-four states had enacted them. In the absence of constitutional bans on special charters, however, the legislatures in these states could, and usually did, continue to dispense economic privileges to their supporters, and that limited the statutes' utility. Thus five years after the enactment of Pennsylvania’s 1849 general incorporation law for manufacturing less than a dozen companies had actually incorporated under it, although in 1855 alone the legislature passed 196 special bills to charter or amend the charters of for-profit business corporations. Many of the private bills were sought by enterprises whose businesses were not yet covered by the general laws, but others were attempts to secure more favorable provisions than the general statutes allowed. For example, iron companies obtained special charters that enabled them to buy stock in other companies (purchases that were otherwise prohibited), engage in lines of business not otherwise permitted (such as building a railroad or a telegraph), borrow money in greater amounts than the law permitted, escape limits imposed on real estate holdings, and set non-standard voting rules for corporate elections. ${ }^{27}$

${ }^{27}$ See, for examples, Pennsylvania General Assembly, “AN ACT To enable the Sharon 
Pennsylvania and most other states with similar arrangements revised their constitutions over the next couple of decades to ban special charters, but they paid an economic penalty for the delay. Some idea of the effect of the lag on economic dynamism can be obtained by comparing the number of incorporations in Ohio, which banned special charters in 1851, with those in New Jersey and Pennsylvania, which enacted general incorporation laws in the 1840s but did not ban special charters for two more decades. During the ten years that followed the Civil War, Ohio chartered 2.2 times more corporations under its general law than New Jersey did under both its general and special laws. Only after New Jersey banned special charters in 1875 did the gap begin to close. During the 1880s (that is, before New Jersey revised its statute to attract out-ofstate corporations), the ratio of new corporations in Ohio relative to New Jersey fell to 1.5, while the number of corporations founded in both states rose dramatically. Although there are gaps in the data for Pennsylvania, the story was much the same, with the number of corporations there converging on Ohio only after the state banned special charters in $1874 .^{28}$

Iron Company, of Mercer county, to subscribe to the Stock of the Pittsburg and Erie Railroad Company,” 5 April 1855; “AN ACT to incorporate the Hopewell Coal and Iron Company,” 7 May 1855; “AN ACT To incorporate the Saucona Iron Company, in the county of Northampton,” 8 April 1857; “AN ACT To incorporate the Sullivan Coal and Iron Company,” 2 March 1868; “AN ACT To incorporate the Emaus Iron Company,” 11 March 1870; “AN ACT Relative to the Bloomsburg Iron Company,” 12 March 1870; “A Further Supplement To an act, entitled 'An Act to incorporate the Emaus Iron Company” ...” 2 April 1872. See also Louis Hartz, Economic Policy and Democratic Thought: Pennsylvania, 1776-1860 (Cambridge, MA: Harvard University Press, 1948), 39-41; and Naomi R. Lamoreaux, "Revisiting American Exceptionalism: Democracy and the Regulation of Corporate Governance: The Case of Nineteenth-Century Pennsylvania in Comparative Context,” in Enterprising America: Businesses, Banks, and Credit Markets in Historical Perspective, ed. William J. Collins and Robert A. Margo (Chicago: University of Chicago Press, 2015), 25-71 at 40. The evidence in these acts counters Hamill's claim in "From Special Privilege to General Utility” that special charters were little different in their salient features than charters obtained under general laws.

${ }^{28}$ George Heberton Evans, Jr., Business Incorporations in the United States, 1800-1943 (New York: National Bureau of Economic Research, 1948), 12, and Appendix 3. 
The constitutional revisions that the states, and especially Indiana, enacted in the wake of the defaults changed the norms for how new state governments should be set up. As Table 2 indicates, five of the six states that entered the union between 1840 and the Civil War (that is, all but Texas) imposed constitutional bans on special corporate charters, and three of the four that wrote constitutions after 1841 required all laws to be general. The case of Kansas is especially interesting because it shows how pervasive the new ideas were. Settlers in that war-ravaged territory wrote four different constitutions between 1855 and 1859. Three of the constitutionsTopeka (1855), Leavenworth (1859), and Wyandote (1859, the one accepted by Congress) — proposed that Kansas be admitted as a free state. All three included virtually identical bans on special charters of incorporation and a requirement that laws had to be general. Thus the Wyandote constitution prohibited the legislature from conferring corporate powers by special act, allowing that "Corporations may be created under general laws; but all such laws may be amended or repealed." It also declared that "in all cases where a general law can be made applicable, no special law shall be enacted" and that "[a]ll laws of a general nature shall have a uniform operation throughout the State.” Even the pro-slavery Lecompton constitution (1857) leaned in the same direction, though its wording was narrower: "The Legislature shall have no power to grant divorces, to change the names of individuals, or direct the sales of estates belonging to infants or other persons laboring under legal disabilities, by special legislation, but by general laws shall confer such powers on the courts of justice.” Its section banning special charters of incorporation was also somewhat weaker (or perhaps just poorly drafted):

“Corporations may be formed under a general law, but the Legislature may by special act create bodies politic for municipal purposes, where the objects of the corporations cannot be attained 
under it. All general laws or special acts enacted under the provisions of this section, may be altered, amended, or repealed by the Legislature at any time.”29

After the Civil War, the constitutional reforms pioneered by Indiana continued to spread. As Figure 1 shows, almost all the states that entered the union in the late nineteenth or early twentieth century incorporated both the ban on special charters and the mandate that all laws be general into their constitutions, as did most Southern states when they rewrote their constitutions after the Civil War. Only a few states never adopted the reforms. Most of the holdouts were in New England, where legislatures had effectively opened access to banking and the corporate form by statute during the preceding decades and, as a consequence, the award of economically valuable privileges to favorites was not an important driver of political discord during the 1840 s and 1850s. The federal government also never adopted the reforms. Indeed, Congress continued to enact private bills, mainly to grant pensions and allow specific immigrants to enter the country, until it voluntarily curbed (but did not eliminate) the practice with the Administrative Procedures and Legislative Reorganization Acts of $1946 .{ }^{30}$

${ }^{29}$ Kansas Historical Society, https://www.kshs.org/kansapedia/kansasconstitutions/16532.

${ }^{30}$ In 1853 Massachusetts submitted a new constitution to voters that included a ban on special charters of incorporation. The constitution was defeated because it would have reduced the representation of Boston and other coastal cities in the legislature. Thomas H. O'Connor, "Irish Votes and Yankee Cotton: The Constitution of 1853," Proceedings of the Massachusetts Historical Society 95 (1983): 88-99; Eli A. Glasser, "Government and the Constitution (18201917)," in Commonwealth History of Massachusetts, ed. Albert Bushnell Hart (New York: States History Co., 1930), Vol. IV, 1-34 at 18-22. On the federal government, see Maggie McKinley (now Blackhawk), "Petitioning and the Making of the Administrative State," Yale Law Journal 127 (Apr. 2018): 1538-1637; and Matthew Mantel, "Private Bills and Private Laws," Law Library Journal 99 (Winter 2007): 87-100. 


\section{A New Political Economy}

After Indiana and other states revised their constitutions to prohibit special and local laws, their legislatures got to work enacting new sets of general statutes. Once this job was completed, they had much business to conduct. Where mandated by their constitutions, they shifted to biennial sessions. Even so, the number of bills they enacted at each session plummeted (see Table 1 for an example). Other parts of the government now handled tasks that had previously taken up a considerable amount of legislative time. Some matters that required the exercise of discretion—granting divorces, for example—became the exclusive responsibility of the courts. Others, such as decisions about whether to build a road or establish ferry service across a river, went to local administrative bodies. Still others, for all practical purposes, went to nobody. Forming a manufacturing corporation, for instance, became in most places a simple registration process. In Indiana all it took was for three or more persons to "make, sign, and acknowledge" before "some officer capable to take the acknowledgement of deeds" a certificate that stated such basic information as the company's name, its business object, the amount of its capital, and the names of its initial officers. Most other states had similar procedures in which no governmental official did more than check to see that the certificate included all the necessary information and the requisite filing fees had been paid. ${ }^{31}$

This lack of regulatory scrutiny of the incorporation process has prompted many scholars to consider the enactment of general incorporation laws as marking a shift toward laissez faire. This is a misunderstanding, however. The constitutional reforms enacted in the wake of the

${ }^{31}$ Indiana General Assembly, "AN ACT for the incorporation of Manufacturing and Mining Companies ...” approved May 20, 1852; Hilt, "Corporation Law.” For the fall in legislative business, see Naomi R. Lamoreaux and John Joseph Wallis, "Making Rules Impersonal: The Historical and Institutional Foundations of General Laws in the United States," unpublished working paper (2019). 
fiscal crisis of the early 1840s were shaped by small-scale producers' resentment against the privileges that legislators had conferred on political favorites. So were the general incorporation statutes that followed, and they aimed to level the playing field and keep it as flat as possible. Many had ceilings on the amount of capital a corporation could raise or the extent to which it could borrow, as well as on the duration of charters. All imposed additional liabilities on shareholders under specific circumstances. (In California shareholders were unlimitedly liable for their proportion of all corporate debts, a rule that persisted deep into the twentieth century.) All also mandated particular governance structures, with some imposing voting rules that curbed the power of the wealthiest shareholders within the enterprise. Although the ceilings on capital and duration tended to become less binding or even to disappear as states revised their laws in the post-Civil War era, the laws continued to limit firms' ability to grow large by making mergers difficult and by prohibiting companies from holding stock in other corporations. Moreover, many states imposed additional liabilities on those in control and bolstered the position of small shareholders by mandating cumulative voting in elections for corporate directors. A number of states even embedded these regulations in their constitutions. ${ }^{32}$

The success of these efforts to level the playing field can be seen in the surging number of small- and medium-sized enterprises that organized as corporations. The most complete data come from George Heberton Evans who compiled counts of the number of new corporations

${ }^{32}$ On general incorporation and laissez faire, see Hurst, Legitimacy of the Business Corporation; Hartz, Economic Policy and Democratic Thought; Ronald E. Seavoy, "LaissezFaire: Business Policy, Corporations, and Capital Investment in the Early National Period," in Encyclopedia of American Political History, ed. Jack P. Greene (New York: Charles Scribner's Sons, 1984), Vol. 2, 728-737. On the regulatory content and effect of state general incorporation statutes, see Lamoreaux, “Corporate Governance”; and Ron Harris and Naomi R. Lamoreaux, "Opening the Black Box of the Common-Law Legal Regime: Contrasts in the Development of Corporate Law in Britain and the United States in the Late Nineteenth and Early Twentieth Centuries,” Business History 61 (Oct. 2019): 1199-1221. 
formed in each state with usable records. Wherever the data allowed, Evans divided corporations into three size categories: small (less than $\$ 100,000$ in authorized capital), medium ( $\$ 100,000$ to $\$ 1,000,000$ ), and large (more than $\$ 1,000,000$ ). As the number of corporations grew over the last third of the nineteenth century, so did the proportion that were small—in Maryland from about 10 percent to more than three quarters of the total, in Ohio from 40-50 percent to over 80 percent, in Texas from about 50 percent to 90 percent. The only state that displayed a different trend was New Jersey, which liberalized its general laws in 1888 to facilitate mergers and legalize holding companies and thus attract large corporations from other states. But even in New Jersey about half of the new corporations chartered in the 1890s were small. The first complete count of the stock of corporations in existence was produced by the Internal Revenue Service, following the imposition of the income tax in the early twentieth century. Again, the overwhelming majority of corporations were small. Of the nearly 200,000 corporations that reported positive net income in 1919, for example, more than three quarters had less than $\$ 100,000$ in capital and most considerably less. ${ }^{33}$

Of course, some large firms found ways to evade the restrictions in the statutes and grow big enough to dominate their industries. Standard Oil's lawyers showed the way by adapting the contractual device of the trust to form what was essentially a holding company and thus assert managerial control over 90 percent of the nation's petroleum refining capacity. As other large firms followed Standard Oil’s example, however, a number of state attorneys general filed suit (usually successfully) to revoke the charters of corporations that participated in trusts. At the same time, states passed antitrust laws that made it illegal to combine by any method to

${ }^{33}$ Evans, Business Incorporations, Appendix 3; Commissioner of Internal Revenue, Statistics of Income (Washington: Government Printing Office, 1922), 14. 
monopolize trade, and they began to invest in building up the regulatory capacity they needed to enforce these statutes. In most states that meant beefing up the office of the attorney general, but a number of Western states established—sometimes constitutionally, sometimes by statuteindependent regulatory agencies called corporation commissions. Modeled on the railroad commissions that more than a score of states had already set up, these bodies assumed responsibility for regulating public service corporations, but they also enforced the general incorporation and antitrust laws. ${ }^{34}$

Large firms attempted to escape these regulatory initiatives by shifting their corporate domiciles to friendlier jurisdictions like New Jersey, which already had legalized mergers and holding companies. According to the standard story, these moves sparked a charter-mongering "race to the bottom" as other states sought to stanch the loss of tax revenues from incorporations. However, the extent of the race has been greatly overstated in the literature. Although many states revised their laws based on New Jersey’s model, their general incorporation statutes remained highly regulatory, even with respect to mergers. For example, the liberalized merger provisions in New York’s 1890 law included the injunction that “[n]o stock corporation shall combine with any other corporation for the prevention of competition," a prohibition that was reiterated when the state again rewrote its general incorporation law in 1909. Similarly, Illinois’s 1919 statute allowed mergers and holding companies, but not if their effect was "substantially to lessen competition.” Even New Jersey backtracked in 1913 when its so-called "Seven Sister"

${ }^{34}$ May, “Antitrust Practice”; Childs, Texas Railroad Commission; Jonathan W. Singer, Broken Trusts: The Texas Attorney General versus the Oil Industry, 1889-1909 (College Station: Texas A\&M University Press, 2002). Examples of state constitutions with provisions for corporation commissions include Oklahoma, 1907 Constitution, Art. 9, Sec. 15 and 43; New Mexico, 1911 Constitution, Art. 11, Sec. 1, 6 and 11; Arizona, 1912 Constitution, Art. 14, Sec. 8 and 17, Art. 15, Sec. 1. 
laws added strict antitrust provisions to its general incorporation laws. Moreover, the states retained considerable regulatory powers over "foreign" corporations—-those chartered in other states—and could exclude combines that violated their antitrust laws. Although the federal government played an increasingly active role in trust busting after the turn of the century, state prosecutions continued, and indeed businesses were still furiously challenging the constitutionality of state initiatives (mostly unsuccessfully) in federal courts at least until the 1920s. ${ }^{35}$

At the same time as businesses pursued these court challenges, they organized to oppose state regulatory initiatives. Before the shift to general laws there had been little need for them to unite for lobbying purposes, except to push Congress for favorable tariff legislation. Instead, businesses had mainly deployed their wealth and influence to secure favors that benefited them individually. After the shift, however, they devoted increasing amounts of financial resources to affect both the content of regulatory legislation and the decisions of the regulators. This development was for the most part new, and it provoked a flurry of muckraking exposes that Richard L. McCormick has characterized as the "discovery that business corrupts politics.” The extent of the outcry, however, was itself an indication of the significant opposition that business faced from a whole host of associations—-ranging from farmers’ cooperatives to labor

${ }^{35}$ Harris and Lamoreaux, “Opening the Black Box”; Bruce G. Carruthers and Naomi R. Lamoreaux, "Regulatory Races: The Effects of Jurisdictional Competition on Regulatory Standards,” Journal of Economic Literature 54 (March 2016): 52-97; New York Legislature, "An Act in relation to stock corporations ..." approved June 7, 1890, §7; Thomas Gold Frost, $A$ Treatise on the Business Corporation Law of the State of New York ... (Albany: Mathew Bender \& Co., 1909), 568; Illinois General Assembly, “Corporations for Pecuniary Profit,” approved June 28, 1919, §7; F. A. Updyke, "New Jersey Corporation Laws,” American Political Science Review 7 (Nov. 1913): 650-652; May, “Antitrust Practice and Procedure”; Ruth H. Bloch and Naomi R. Lamoreaux, "Corporations and the Fourteenth Amendment," in Corporations and American Democracy, ed. Lamoreaux and Novak, 286-325. 
organizations to more elite civic and anti-monopoly leagues - formed to lobby on behalf of the "people." This too was for the most part a new development. Although these associations had antecedents in the anti-slavery and other reform movements of the antebellum period, the shift toward general laws meant that they now had ready access to the organizational tools (including the corporate form) that enabled them to operate, and fundraise, more effectively. ${ }^{36}$

Opponents of big business deployed the same anti-corruption rhetoric at the end of the nineteenth century that Jacksonian-era publicists had earlier used to critique special privileges. And there was certainly plenty of corruption for them to point to. But it is important not to let such continuities in language obscure the profound changes that had occurred in the substance of economic and political interactions, including the way corruption worked. In states that adopted the constitutional revisions, individuals no longer had to seek special legislative favors to obtain divorces or pensions. The same for groups wanting to form corporations. More significantly, legislators no longer had the power to grant the kinds of economically valuable privileges that had been the building blocks of political coalitions in the first half of the century. Now when businesses deployed their wealth, as they inevitably did, in attempts to secure or perpetuate advantages, they faced determined and increasingly well-organized opposition from a host of antimonopoly associations. In some times and places big-business interests prevailed; in others, the antimonopolists. The rules had changed, and outcomes were not anywhere foreordained. ${ }^{37}$

${ }^{36}$ Richard L. McCormick, "The Discovery That Business Corrupts Politics: A Reappraisal of the Origins of Progressivism,” American Historical Review 86 (Apr. 1981): 247274; Richard R. John, "Robber Barons Redux: Antimonopoly Reconsidered,” Enterprise \& Society 13 (Mar. 2012): 1-38; Clemens, People’s Lobby; Ruth H. Bloch and Naomi R. Lamoreaux, "Voluntary Associations, Corporate Rights, and the State: Legal Constraints on the Development of American Civil Society, 1750-1900," in Organizations, Civil Society, and the Roots of Development, ed. Lamoreaux and Wallis, 231-290.

${ }^{37}$ It is beyond the scope of this paper to provide a full picture of these changes, but that is the aim of our larger research project. For both continuities and changes in corruption, see 
General laws made the economic and political system more competitive, but they did not in and of themselves bring full equality. Legislatures could still group people and businesses into categories and, so long as they treated members of each group the same, they could treat the groups differently. Such categorization facilitated economic regulation (for example, it enabled legislatures to impose more stringent rules on railroads than other businesses), but it also legitimated racial discrimination (the Jim Crow laws that mushroomed in the late nineteenth century). Nonetheless, the requirement that laws be general gave groups disadvantaged by such classifications a legal weapon they could use to push back. Businesses mainly lost the battles they waged against regulation in the courts, but minority groups would gradually prevail. Of course, other developments contributed to these outcomes, but it is difficult to imagine either occurring in a world where legislatures routinely conferred favors on particular individuals or groups. In such a world, regulatory legislation could never be effective. Nor would it be possible to achieve equality before the law. ${ }^{38}$

Richard White, The Republic for Which It Stands: The United States during Reconstruction and the Gilded Age, 1865-1896 (New York: Oxford University Press, 2017); and Wallis, Concept of Systematic Corruption.” On regulatory achievements, see May, "Antitrust Practice”; William J. Novak, "Law and the Social Control of American Capitalism," Emory Law Journal 60 (issue 2, 2010): 378-405; and Naomi R. Lamoreaux, "The Problem of Bigness: From Standard Oil to Google,” Journal of Economic Perspectives 33 (Summer 2019): 94-117.

${ }^{38}$ On businesses' failure to block most regulatory legislation, see Bloch and Lamoreaux, "Corporations and the Fourteenth Amendment." 
Table 1. Types of Laws Enacted by the Indiana Legislature, Select Years, 1830-1885

\begin{tabular}{|c|c|c|c|c|c|c|c|c|c|}
\hline Year & $\begin{array}{c}\text { Total } \\
\text { Number } \\
\text { of Laws }\end{array}$ & $\begin{array}{c}\text { General } \\
\text { Laws }\end{array}$ & $\begin{array}{c}\text { General } \\
\text { Laws as } \\
\text { Percent } \\
\text { of Total }\end{array}$ & $\begin{array}{c}\text { Special } \\
\text { Laws for } \\
\text { State } \\
\text { Govern- } \\
\text { ment }\end{array}$ & $\begin{array}{c}\text { Special } \\
\text { Laws for } \\
\text { State } \\
\text { Govern- } \\
\text { ment as } \\
\text { Percent } \\
\text { of Total }\end{array}$ & $\begin{array}{l}\text { Local } \\
\text { Laws for } \\
\text { Local } \\
\text { Govern- } \\
\text { ments }\end{array}$ & $\begin{array}{l}\text { Local } \\
\text { Laws for } \\
\text { Local } \\
\text { Govern- } \\
\text { ments as } \\
\text { Percent } \\
\text { of Total }\end{array}$ & $\begin{array}{c}\text { Private } \\
\text { Laws }\end{array}$ & $\begin{array}{c}\text { Private } \\
\text { Laws as } \\
\text { Percent } \\
\text { of Total }\end{array}$ \\
\hline \multicolumn{10}{|c|}{ Panel A: Legislative sessions held before the 1851 Constitution } \\
\hline 1830 & 118 & 2 & 0.02 & 8 & 0.07 & 83 & 0.70 & 25 & 0.21 \\
\hline 1835 & 247 & 28 & 0.11 & 8 & 0.03 & 132 & 0.53 & 79 & 0.32 \\
\hline 1840 & 307 & 39 & 0.13 & 31 & 0.10 & 156 & 0.51 & 81 & 0.26 \\
\hline 1845 & 496 & 49 & 0.10 & 28 & 0.06 & 248 & 0.50 & 171 & 0.34 \\
\hline 1850 & 550 & 43 & 0.08 & 16 & 0.03 & 278 & 0.51 & 213 & 0.39 \\
\hline \multicolumn{10}{|c|}{ Panel B: Legislative sessions held after the 1851 Constitution } \\
\hline 1855 & 114 & 74 & 0.65 & 23 & 0.20 & 12 & 0.11 & 5 & 0.04 \\
\hline 1861 & 154 & 86 & 0.56 & 34 & 0.22 & 21 & 0.14 & 13 & 0.08 \\
\hline 1865 & 156 & 97 & 0.62 & 28 & 0.18 & 26 & 0.17 & 5 & 0.03 \\
\hline 1871 & 35 & 14 & 0.40 & 7 & 0.20 & 12 & 0.34 & 2 & 0.06 \\
\hline 1875 & 158 & 104 & 0.66 & 22 & 0.14 & 28 & 0.18 & 4 & 0.03 \\
\hline 1881 & 157 & 91 & 0.58 & 29 & 0.18 & 26 & 0.17 & 11 & 0.07 \\
\hline 1885 & 159 & 85 & 0.53 & 32 & 0.20 & 36 & 0.23 & 6 & 0.04 \\
\hline
\end{tabular}

Notes and Sources: We divide special laws into three categories: “special laws for state government” are those for running different parts of the state government, for example appropriations for the state attorney general or the supreme court; "local laws for local governments” regulated specific local governments, for example by allowing specific taxes or setting salaries for particular officials; 
and "private laws" were bills enacted to benefit specific individuals or groups, for example allowing them to change their names or form corporations. The counts before 1855 include both the volumes for "General Laws” and the volumes for "Local Laws.” After 1851, there was only one volume per legislative session. The counts for 1861, 1865, 1875, 1881, and 1885 include both the regular session and special sessions held during those years. There was no special session in 1855 or 1871 . All laws are from Indiana Session Laws, Heinonline, https://heinonline.org/HOL/Index?index=ssl/ssin\&collection=ssl. 
Table 2. Revisions to State Constitutions, 1840-1860

\begin{tabular}{|c|c|c|c|}
\hline & $\begin{array}{c}\text { Adopted a } \\
\text { New } \\
\text { Constitution? }\end{array}$ & $\begin{array}{c}\text { Banned } \\
\text { Special } \\
\text { Corporate } \\
\text { Charters? }\end{array}$ & $\begin{array}{c}\text { Mandated } \\
\text { General } \\
\text { Laws? }\end{array}$ \\
\hline \multicolumn{4}{|l|}{ States that Defaulted } \\
\hline Arkansas & $\mathrm{N}$ & -- & -- \\
\hline Florida & $\mathrm{N}$ & -- & -- \\
\hline Illinois (1848) & $\mathrm{Y}$ & $\mathrm{Y}$ & $\mathrm{N}$ \\
\hline Indiana (1851) & $\mathrm{Y}$ & $\mathrm{Y}$ & $\mathrm{Y}$ \\
\hline Louisiana (1845 and 1852) & $\mathrm{Y}$ & $\mathrm{Y}$ then $\mathrm{N}$ & $\mathrm{N}$ \\
\hline Maryland (1851) & $\mathrm{Y}$ & $\mathrm{Y}$ & $\mathrm{N}$ \\
\hline Michigan (1850) & $\mathrm{Y}$ & $\mathrm{Y}$ & $\mathrm{N}$ \\
\hline Mississippi & $\mathrm{N}$ & -- & -- \\
\hline Pennsylvania & $\mathrm{N}$ & -- & -- \\
\hline \multicolumn{4}{|l|}{ Other States with High Debts } \\
\hline Alabama & $\mathrm{N}$ & -- & -- \\
\hline Massachusetts & $\mathrm{N}$ & -- & -- \\
\hline New York (1846) & $\mathrm{Y}$ & $\mathrm{Y}$ & $\mathrm{N}$ \\
\hline Ohio (1851) & $\mathrm{Y}$ & $\mathrm{Y}$ & $\mathrm{N}$ \\
\hline South Carolina & $\mathrm{N}$ & -- & -- \\
\hline Wisconsin (1848) & $\mathrm{Y}$ & $\mathrm{Y}$ & $\mathrm{N}$ \\
\hline \multicolumn{4}{|l|}{ States with Low or No Debts } \\
\hline Connecticut & $\mathrm{N}$ & -- & -- \\
\hline Delaware & $\mathrm{N}$ & -- & -- \\
\hline Georgia & $\mathrm{N}$ & -- & -- \\
\hline Kentucky (1850) & $\mathrm{Y}$ & $\mathrm{N}$ & $\mathrm{N}$ \\
\hline Maine & $\mathrm{N}$ & -- & -- \\
\hline Missouri & $\mathrm{N}$ & -- & -- \\
\hline New Hampshire & $\mathrm{N}$ & -- & -- \\
\hline New Jersey (1844) & $\mathrm{Y}$ & $\mathrm{N}$ & $\mathrm{N}$ \\
\hline North Carolina & $\mathrm{N}$ & -- & -- \\
\hline Rhode Island (1843) & $\mathrm{Y}$ & $\mathrm{N}$ & $\mathrm{N}$ \\
\hline Tennessee & $\mathrm{N}$ & -- & -- \\
\hline Vermont & $\mathrm{N}$ & -- & -- \\
\hline Virginia (1851) & $\mathrm{Y}$ & $\mathrm{N}$ & $\mathrm{N}$ \\
\hline \multicolumn{4}{|l|}{ New States } \\
\hline California (1849) & $\mathrm{Y}$ & $\mathrm{Y}$ & $\mathrm{N}$ \\
\hline Iowa (1846 and 1857) & $\mathrm{Y}$ & $\mathrm{Y}$ & $\mathrm{N}$ then $\mathrm{Y}$ \\
\hline Kansas (1859) & $\mathrm{Y}$ & $\mathrm{Y}$ & $\mathrm{Y}$ \\
\hline Minnesota (1857) & $\mathrm{Y}$ & $\mathrm{Y}$ & $\mathrm{N}$ \\
\hline Oregon (1857) & $\mathrm{Y}$ & $\mathrm{Y}$ & $\mathrm{Y}$ \\
\hline Texas (1845) & $\mathrm{Y}$ & $\mathrm{N}$ & $\mathrm{N}$ \\
\hline
\end{tabular}


Notes and Sources: Louisiana banned special corporate charters in 1845 but omitted that provision when it rewrote its constitution in 1852. Iowa did not mandate general laws in its 1846 constitution but added the provision when it rewrote its constitution in 1857. The defaulting states that did not rewrite their constitutions during this period all had just written new constitutions in the 1830s. Three additional states wrote revised constitutions in the 1840s or 1850s that were rejected by the voters: Delaware (1853), Massachusetts (1853), and Missouri (1845). Only the Massachusetts draft would have prohibited special corporate charters. States were considered to have high debts if their obligations exceeded \$5 per capita. See Wallis, “Constitutions, Corporations, and Corruption,” 217. Constitutional provisions are from the NBER/Maryland State Constitutions Project, http://www.stateconstitutions.umd.edu/index.aspx. For a list of state constitutional conventions from the period, see John J. Dinan, The American Constitutional Tradition (Lawrence: University Press of Kansas, 2006), 8-9. 
Figure 1. Comparison of Dates of Constitutional Mandates for General Incorporation and General Laws, by States

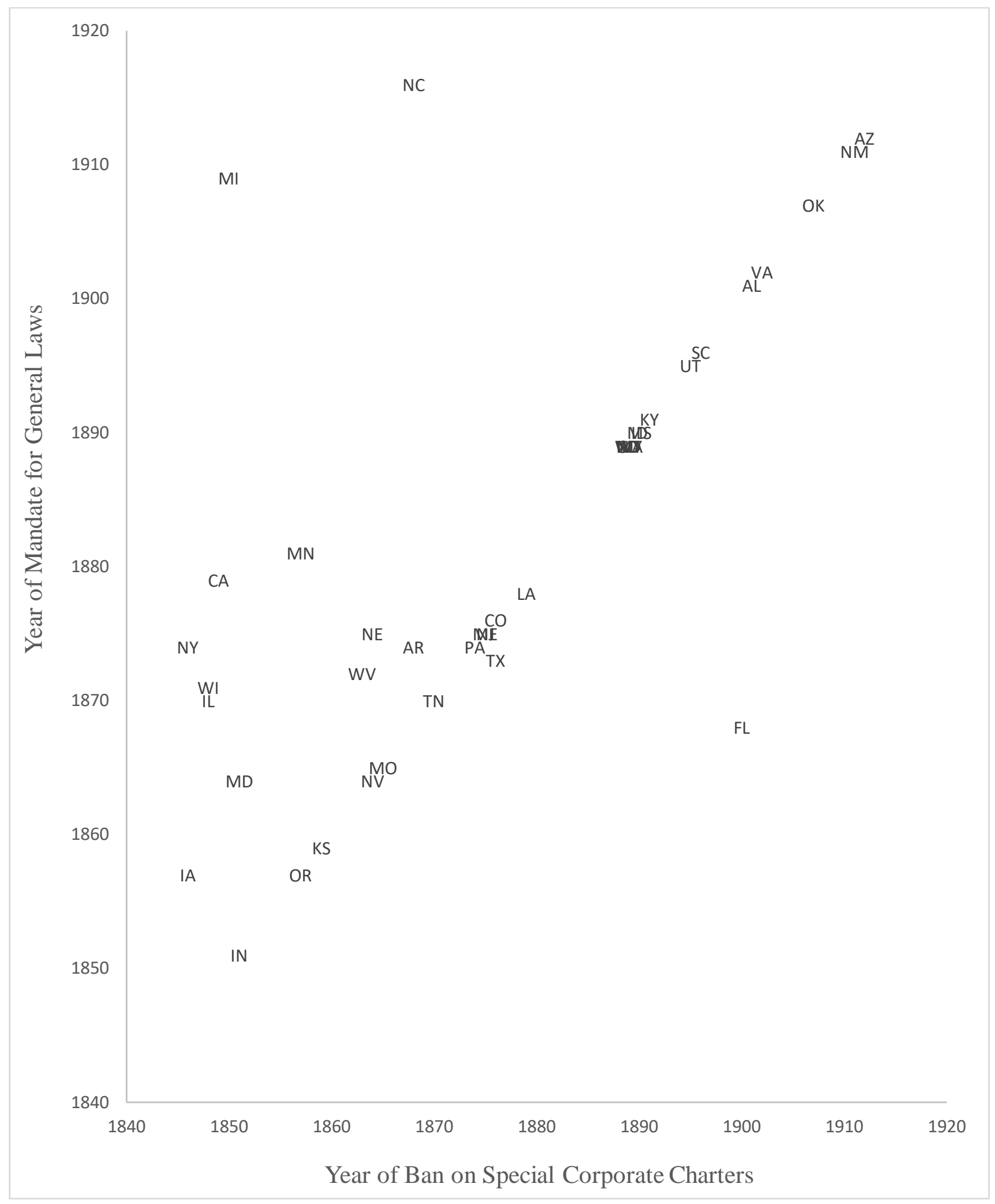


Notes and Sources: Delaware, Georgia, Ohio, and Vermont banned special corporate charters (in 1897, 1890, 1851, and 1913 respectively) but did not enact mandates for general laws.

Connecticut, Massachusetts, New Hampshire, and Rhode Island did not enact either provision. Florida's 1868 constitution included a long list of topics on which the legislature was forbidden to enact special and local legislation, as well as a requirement that laws be general wherever possible. The latter clause was dropped from the 1887 constitution, though the list of prohibitions expanded. In 1879 Louisiana similarly weakened its mandate for general laws. The state also went back and forth on the ban on special corporate charters, imposing it in 1845, dropping it in 1852, imposing it in 1864, dropping it in 1868, and then adopting it permanently in 1879. For the text of the constitutional provisions see the NBER/Maryland State Constitutions Project, http://www.stateconstitutions.umd.edu/index.aspx. Provisions not available on the website can be obtained from John Wallis. 
Figure 2. The Mammoth System of Internal Improvements

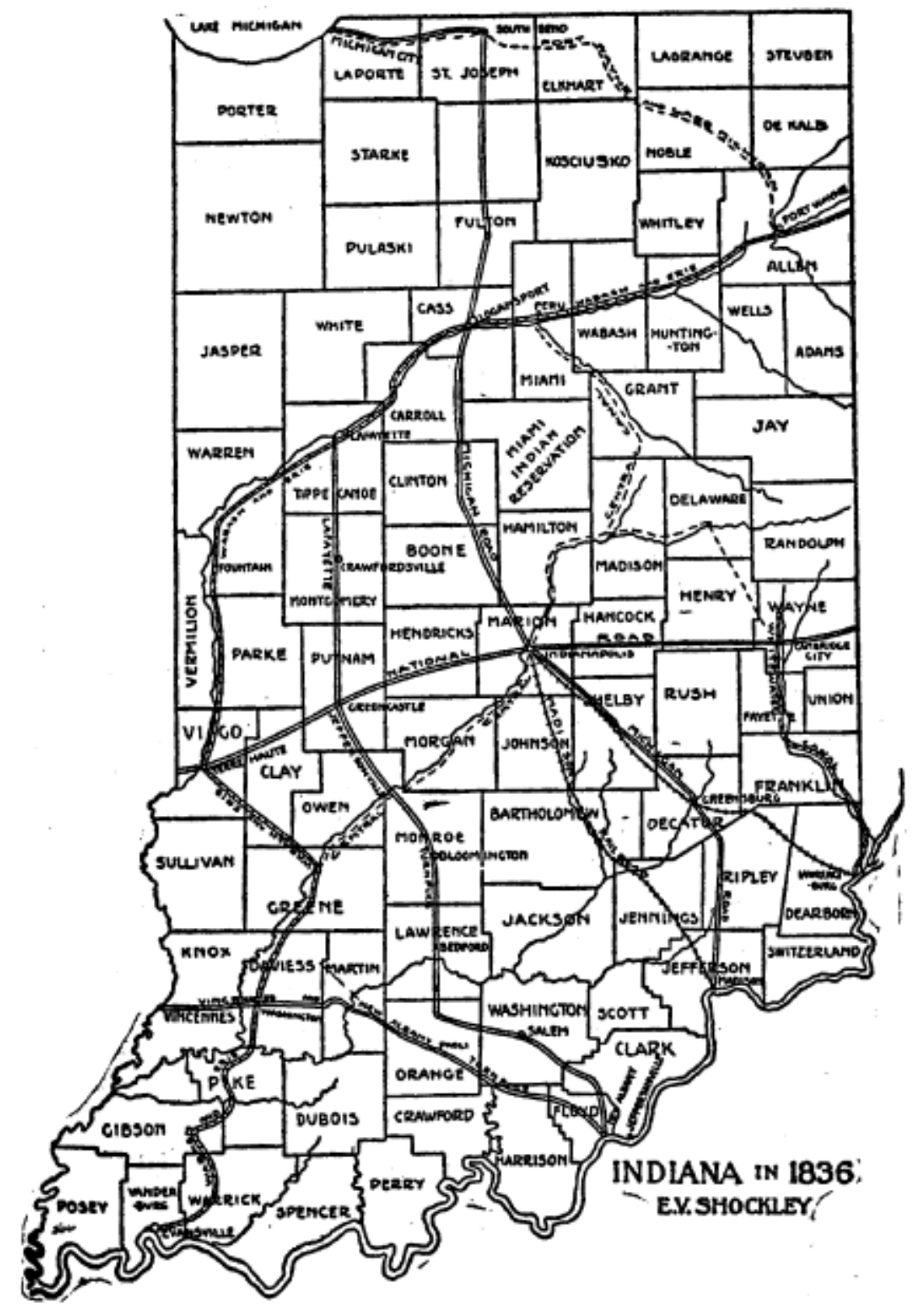

Source: Reproduced from Esarey, History of Indiana, Vol. 1, 355. 